\title{
Reindeer-breeding culture in Russia and Inner Mongolia (PRC) (based on the material of the reindeer-breeding vocabulary of the Evenks)
}

\author{
Tamara Andreeva ${ }^{*}, 2$, Elizaveta Afanasieva ${ }^{3}$, Natalia Ushnitskaya $^{1}$, Kirill Struchko ${ }^{1}$ \\ ${ }^{1}$ Institute of Humanities and Indigenous Peoples of the North, SD RAS, 1 Petrovskogo Street, Yakutsk, Sakha Republic (Yakutia), \\ 677027, Russian Federation. \\ ${ }^{2}$ Institute of Languages and Cultures of the Peoples of the Northeast, Ammosov NEFU, 42 Kulakovskogo Street, Yakutsk, Sakha \\ Republic (Yakutia), 677018, Russian Federation. \\ ${ }^{3}$ Buryat State University named after D. Banzarova, 1. Smolina STR, Ulan-Ude, Republic of Buryatia, 670000, Russian Federation. \\ 2. 104, Revolution STR, Ulan-Ude, Buryatia, Russian Federation 3
}

\begin{abstract}
The article is dedicated to a comparative study of the vocabulary of the Evenks of Russia and China, reflecting the Evenks' reindeer-breeding culture. Reindeer is of key importance in the spiritual culture of the Tungus. This is due to the economic and cultural type of the Evenks - reindeer herders. Reindeer is the most common domestic animal of the Evenks. Its breeding and economic use is now typical for all Tungusic peoples of Russia and China. Therefore, the main purpose of the article is to describe the ethnolinguistic and ethnocultural realia of the worldview of the Evenks of Russia and China.
\end{abstract}

\section{Introduction}

The language of any people is considered as a historical source, the whole life of the people finds a peculiar reflection in its language. The purpose of this article is a comprehensive description of the vocabulary reflecting the reindeer-breeding vocabulary of the Evenks of Russia and China.

The Evenks of China are represented by four ethnolinguistic groups, joined in two official nationalities, living in Hulunbuir Region of the Inner Mongolia Autonomous Region (hereinafter referred to as the IMAR) and in Heilongjiang Province: Oroqen people and the Evenks. They are the Oroqen people (literally “reindeer herders") (Chinese 鄂伦春族, Pinyin ÈlúnchūnZú). According to the information Internetcenter, the 2010 census registered 8659 people: $44,54 \%$ live in Inner Mongolia, 51,52\% - in Heilongjiang Province, $1,2 \%$ - in Liaoning Province; Evenks (Chinese 鄂温克族, Pinyin EwēnkèZú) - 30505 by the 2000 census, of them $88,8 \%$ live in Hulunbuir: Solon people, Yako-Tungus people, Hamnigan people. The specified groups of the Evenks have begun to distinguish per the Decree of China's government since 1951.

In 1951, Oroqen Banner was established in the IMAR; Evenki Banner was established in 1958. in 1957, based on the desire of both groups' representatives, they were given a joint name - Ewenki (Evenks). Each local group preserved its native name. For example, Solon people, Tungus Evenks known as Hamnigan Evenks, and a group of so-called Yakuts - Yako-Evenks consider themselves Evenks. Oroqen people do not consider themselves Evenks, they call themselves "Oroqen beye".

The Evenks of Russia live on the vast territory of Russia, from Sakhalin to the Ural, as well as in Mongolia and the Inner Mongolia of the PRC.

The Associations of Evenks of Yakutia and Buryatia have visited Evenki Banner quite often. Buryat State University has close links with Evenki Banner of the Chinese IMAR. The University invited us to the expedition $(2009,2013,2014)$.

The main goal of the expedition was studying the ethnolinguistic and ethnocultural realia of the worldview of the Evenks of Russia and China. During the expedition the students and the teachers got acquainted with different local groups of the Evenks of China, living in the IMAR - Solon people, Yako-Evenks of Evenki Banner, Oroqen people of Oroqen Banner, Tungus Evenks (Hamnigan) of Starobargutsky Banner, their lifestyle, culture, and language peculiarities. China hosted the $5^{\text {th }}$ World Reindeer Herders' Congress; it was held in Aoluguya area in the vicinity of Genhe City in the northeast China on July 25-28, 2013; it is a unique cultural and professional event that brings together the representatives of reindeer breeding peoples from the entire circumpolar region.

\section{Materials and methods}

The research was carried out using the method of continuous sampling of lexemes on the selected theme from lexicographic sources; the method of comparative 
analysis - to determine the semantics and identify the common and the different.

The main sources were as follows: Evenk-Russian dictionary, fieldwork materials of the authors, documented from native speakers, living in China and Russia. Informants: 1) old woman Anta (settlement of Alaguya, northeast China, belongs to the group of Evenks called "Tungus-Yako" in China, speaks Chinese and Evenk languages; 2) A. P. Avelova, born in 1932, Khandyga settlement, Tomponsky District, SR (Y), 3) Yu. Yu. Malchakitov, born in 1960, Kust-Kemda settlement, Kalarsky District, Zabaikalsky Krai.

\section{Results and Discussion}

Reindeer breeding, hunting and fishing are the main types of traditional economic activities of the Evenks of Russia. "Reindeer husbandry - one of the main activities of the Evenks - has remained such to this day, which gives them the opportunity to preserve and pass on the language and culture to the younger generation. From time immemorial, reindeer has been food, transport, clothing, and home for an Evenk. But this is not its only role in the life of the taiga nomad and hunter, reindeer is a part of his language and culture. Since olden times, Evenks have been migrating by the seasons: from a summer camp to an autumn camp, from an autumn camp to a winter camp, from a winter camp to a summer camp. Such is the way of the annual cycle. The migration depends on reindeer food (lichen) and on hunting". [4, p. 233].

The study of vocabulary as a system attracts the attention of many linguists. To describe particular fragments of any language's vocabulary, they usually use a classification by thematic and lexical-semantic word groups (hereinafter TG and LSG). In the article, the TG describes the Evenks' reindeer-breeding culture, whereas the LSG is a pool of words related to one part of speech and semantically correlated with each other by lexical meanings. The Evenks' reindeer-breeding terms are considered by subgroups: general names of reindeer irrespective of gender and age, age and gender names of reindeer, 3) reindeer names by their external characteristics, etc.

LSG for general names of reindeer:

Орон (oron) - a home reindeer.

Сагдаку (sagdaku) - an old reindeer.

Бодовун- (bodovun) a reindeer outside the caravan.

Учак, миинэр (uchak, miiner, Yakut word) - a saddle reindeer.

Инивугдэн- (inivugden) a baggage reindeer

Эннэмэвур- (ennemevur) a female reindeer, to which a young reindeer is tied at night.

Кувэо, буур (kиvео, buиr, Yakut word) - a castrated bull.

LSG reindeer in pack-up and sledge transport:

Угучак (uguchak)- reindeer-saddle

Наманки (namanki)- reindeer of burden

Борракй (boraki) - reindeer that stretches forward in a bundle.
Турин (turin) - reindeer that stretches

Бурики (buriki) - to creep a pack back to the reindeer.

Нёкото (nyokoto) - to creep a pack forward to the reindeer neck

Пескарук (peskaruk) - reindeer that carries the stove

Һулларук (hullaruk) - reindeer that carries blankets

Дагаптук (dagaptuk) - reindeer tied reindeer-saddle

Дэлэмин (delemin) - reindeer freely running after a caravan during the transfer

Баретчит (baretchit)- reindeer is an advanced on the sledge

Модурэ̄ $\mu$ (moduren)- reindeer is stuck with a leash behind the trees during the transfer

LSG general names of reindeer excluding gender and age:

Бэюнчика̄н (beunchika)- crossbreed wild and domestic reindeer.

Эка $(e k a)$ - reindeer is not accustomed to the pack.

Эмник (emnik) - wild reindeer

Нёрамну (nyoramnu) - reindeer-leader in the herd

Hāpā(nara) -non-holodden reindeer male

Акта (akta)- holodden reindeer

Онгӯн (ongun)- holy reindeer.

Оро̄ты (oroty) - late calf

Идэһэ (idehe) - reindeer for the slaughter

LSG for age and gender reindeer names:

Сонна (sonna) - a newborn reindeer.

Эннэкэн (enneken) - a young reindeer.

Тарагай (taragai) -a reindeer under the age of 1 year.

Эвкан, мулкан, чоноку (evkan, mulkan, chonoku) a 1-year-old male reindeer.

Хорой (khoroy) - a male reindeer under the age of 2 years.

Иктэнэ (iktene) - a reindeer between 2 to 3 years of age.

Негаркан (negarkan) - a reindeer between 3 to 4 years of age.

Муты (muty) - a male reindeer between 4 to 35 years of age.

Гилгэ, буур (gilge, buur, Yakut word) - a reindeer over 5 years of age.

Hapa (nara) - a not fully castrated reindeer.

Сачари - (sachari) a female deer between 1 to 2 years of age.

Энни - (enni) a female reindeer who has dropped a calf under 1 year of age.

Нями - (nyami) a female reindeer.

Умири - (umiri) a female reindeer who has lost its calf.

Вангай, кэтэм - (vangai, ketem) a non-calving female reindeer.

Сурки (surki)- pregnant female reindeer.

Дулак (dulak) - not pregnant female reindeer

Байтасын - (baitasyn) a female reindeer who has lost its calf.

Делаг, кытарах (delag, kytarakh, Yakut word) - a dry female reindeer. 
LSG of reindeer names by external characteristics: by color:

Мэнты - (menty) a brown reindeer

Коннорин, конномо - (konnorin, konnomo) black.

Бурдалай-(burdalai) a grey-brown reindeer.

Синулэ - (sinule) a black-brown reindeer.

Борон, боронкон (boron, boronkon, Yakut word) grey.

Багдарин - (bagdarin) white.

by the horns' shape:

Тымбурэ, тэпули, иеачин- (tynbure, tepuli, ieachin) hornless reindeer. horns.

Лэндумэ- (lendume) a reindeer with branching

\section{by character:}

Хулгэн, тэһии- (hulgen, tehi) a wild reindeer ungiving to catching.

Кукэин- (kukein) a savage butting reindeer.

Бузуй - (buzui) a restless reindeer.

LSG of reindeer pack-up and sledge harness:

Ины (iny)- pack

Тэнынэ (tenyne) - bedsp on top of the saddle

Ламба (lamba) - double -pack for transporting cargo

Чомпули (chompuli) - pack pouch for blanket

Доптун (doptun) - reindeer bedding on the back on the saddle.

Инмэк (inmek) - birch bark-based pack.

Тынэптун (tyngeptun) - girth.

Тэ̄ри(teri) -1.pair; 2.couple of a pack

Уhи (uhi) -bridle

LSG reindeer care:

Kype (kure) - reindeer hedge.

Голопко (golopko) - pole to tie the calf.

Чэ̄џгэ̄й (chengei) - wooden collar of the reindeer. A stick is hung on it not to let reindeer go far away

Самуин (samngin) - smoker.

Самниксан (samngiksan) - smoker place.

Туррукэрӯк (turukeruk)- sack with rattles in which the salt for reindeers

Кэугйлэ̄н (kengilen)- bell on the deer's neck

Капкаптунн (kapkatun)-temporary deer leash

Моуолон (monolon)- permanent deer leash

Мayт (maut) - lasso

\section{Saddles and backpacks:}

Нэмэ - (nете) a saddle.

Эмэгэн - (emegen) a pack saddle.

Икэвье - (ikevie) a pack pouch.

Бото - (boto) a saddle cloth.

Данды - (dandy) side boards of the saddle, and others.

LSG names of sites. Each site has its name in accordance with the season.

Дюгакит (dyugakit) -

1) a place where summer is spent; 206].
Болодёкит (bolodyokit) - a place where autumn is always spent; autumn site <боло (bolo) 'autumn'[6, p 94].

Тугэрмэкит (tugermekit) - a path (winter) <тугэни (tugeni) - winter [6, p. 617].

Неңнедекит (nennedekit) - spring site; a place where spring is always spent <nenneni 'spring' $[6, \mathrm{p}$. 420].

LSG of dwelling names could also be of seasonal nature, for example, тугэрук (tygeruk) - winter dwelling) [6, p. 617].

For the Evenks, reindeer is not only a vehicle, a source of shelter and food, but also a huge spiritual world. The migrations continue from spring to deep snow for hunting and for reindeer need for different kinds of food. In July and August, reindeer are driven into alpine tundra belt, to the places rich in lichen and yellowwort, protecting the reindeer from gnat. Until the deep snow, there is pack-riding movement, in winter on sledges. Reindeer are supervised all the time, so they migrate with all the livestock. If the livestock is numerous, there are special drovers. If wolves appear nearby, they migrate a long distance away. Late Aprilearly May is the most important and difficult period for reindeer breeders as young reindeer are born. The protection of the breeding stock from predators at this time requires special attention. Reindeer travel long distances, so reindeer herders build kure hedges. Later, when the young reindeer grow up a little and begin to eat lichen and grass, some reindeer herders milk the females. September is the time of reindeer mating games. It is also a crucial period for reindeer herders. It is important to prepare reindeer for estrus: castration of some of the bulls, migration to a convenient place, notching the spires of the seed bulls. The nomadic way of life of the Evenks is clearly reflected in their language and culture.

Thus, for example, the Evenks have odë (odyo) 'taboos' for using certain parts of reindeer carcass: Эннэрэ бэюе, орон гирамналван дунннәу нодара, дэлкэнмэ оккал. (ennere beyun, oron giramnvalan dunnedu nodara, delkenme okal) - 'You mustn't throw the bones of a wild domestic reindeer on the ground ' and others.

Reindeer herders still remember and follow some customs and perform ceremonies nowadays. For instance, they read fortune from a reindeer or moose shoulder bone called dalu. Cleaned and dried shoulder bone dalu is held above the fire until there appear cracks. These cracks can forecast successful hunting or, vice versa, a trouble. If they haven't seen some family member for a long time, a special ceremony is performed: a reindeer is slaughtered for the reunion. Not having seen each other for a long time (thirty or ten years), they slaughter a reindeer for the reunion, cover their hands with blood without entering the tent and saying "We are blood related, born from one mother and one father" [5].

The only group of Evenks whose main economic activity is reindeer breeding - Tungus-Yako - live in China. That is why, reindeer-breeding vocabulary is 
especially rich in their language. Reindeer are named by age, seasons, and color.

Let's look at some of these names.

LSG for age and gender reindeer names.

эннэкӭн (enneken) - young reindeer.

чоноку (chonoku) - 2-year-old reindeer.

гилгэ (gilge) - working bull.

акта (akta) - castrated reindeer.

cupy (siru) - seed bull.

LSG for color

чэлкээ-(chelke) - white reindeer.

бугды (bugdy) - reindeer with a white nose and legs.

алак (alak) - spotted in color reindeer.

борон (boron) - grey reindeer.

Каракчин (karakchin) - black reindeer,

синарикан (sinarikan) - brown reindeer.

Kalarsky District Evenks have the same LSG for the reindeer names by age as the Chinese ones [5]. For example, a young reindeer is called сонначан sonnachan or эннэкэн enneken. Young reindeer can be

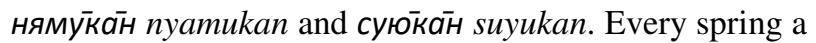
reindeer gets a new name as it gets one year older. At the age of three it becomes иктӭээ iktene. After иктэнээ iktene it becomes суру- suru - a seed bull. Суру- suru also grows older. At the age of five - cypȳ suru. An old cypy suru (seed bull) is called кэтээр keter [5]. Similar age names for a male domestic reindeer: эннэкэн enneken a common name for a young reindeer,

суюкэӭ suyuken - young male reindeer,

чоноку chonoku - 2-year-old male,

иктӭн iktene - 3-year-old male,

нёгаркана nyogarkana-4-year-old male,

сурӯ suru - seed bull,

кэт̈эр keter - 5-year-old seed bull.

Thus, we find similarities in the reindeer-breeding vocabulary of the Evenks of China and Russia, in particular, age and gender names, color names, and others:

эннэкэн еnneken - young reindeer,

чоноку chonoku - 2-year-old male,

чачари chachari - 2-year-old female,

иктӭн iktene - 3-year-old male,

нёгаркана nyogarkana - 4-year-old male,

борон boron - grey,

багдарин bagdarin - white,

коннорин konnorin - black,

синарин sinarin - brown,

бугды bugdy - reindeer with a white nose and legs, алак alak - pied,

мэримэ merime - spotted, and others.

Thus, the Evenks have preserved reindeer breeding as the main traditional activity, despite the technologization of the modern society. For the Evenks, reindeer breeding is a condition for the preservation of their language and culture in the modern conditions.

\section{Conclusion}

Our research has shown that the Evenks possess the qualities inherent only to them: 1) an extraordinary geographical mobility, which probably stems from their hunting and reindeer herding complex; 2) an outstanding ability to adapt to different climatic zones; 3) openness to the new forms of economy and life; 4) poor resistibility to assimilation with their numerous neighbors.

The Evenks of China have preserved their native language, traditions, culture, and beliefs. In contrast, in Russia only the representatives of the older generation can speak their native language well. Every year on June 18, the Evenks of China celebrate the Evenk national holiday "Sebin" ("Reindeer"). In Russia, Evenks celebrate "Bakaldyn" holiday at the end of May, when a cuckoo starts to call $[1$, p. $11-21 ; 6]$.

The main form of economic activity of the Evenks in Russia is hunting; Chinese Evenks were also hunters until the 2000s; at present, hunting is prohibited. The Evenk reindeer herding groups in Russia have also continued their traditional type of farming since ancient times. Depending on the availability of food for reindeer (reindeer lichen) and the hunting season, they migrate throughout the year from a summer camp to an autumn camp, from an autumn camp to a winter camp, from a winter camp to a summer camp. In China, only one group of Yako-Evenks keeps reindeer. Reindeer husbandry is a masterpiece of the intangible heritage of humanity.

The vocabulary reflecting the spiritual culture of the Tungus is an integral component of the traditional culture of the people. The complexity and vivid specificity of this layer of their vocabulary are rooted in the national specificity of the Evenk language. In general, as the material shows, reindeer herding vocabulary is original. There are few foreign language borrowings.

\section{References}

1. E. F. Afanasieva, The Evenks of China Tungusic ethnic groups in the new century: materials of the All-Russian conference with international participation p.11-21 (Ulan-Ude: Publishing House of Buryat State University, 2010).

2. N. Ya. Bulatova, On the Evenks and Oroqen people of Russia and China. The problems of modern functioning of languages and culture of the small-numbered peoples of Tungusic and Turkic groups p. 29-36. (Ulan-Ude: Publishing House of Buryat State University, (2016).

3. S.V. Gomboeva, Oroqen peoples of China Theoretical and methodological issues of studying the language and culture of the smallnumbered peoples: materials of the All-Russian research and practical conference p. 78-82. (Ulan-Ude: Publishing House of Buryat State University, (2015)

4. N. Yu. Ushnitskaya, The vocabulary of the Evenks of China (on the materials of expeditions) Theoretical and methodological issues of 
studying the language and culture of the smallnumbered peoples: materials of the All-Russian research and practical conference p. 113-115. (Ulan-Ude: Publishing House of Buryat State University, (2015).

5. Authors' Fieldwork Materials of Andreeva T.E., Struchkov K.N. (2014), Ushnitskaya N. Yu. (2014, 2015).

6. Myreyeva A. N. Evenk-Russian dictionary = Эвэдыл-лучадытурэрук. (Novosibirsk:Nauka, 2004) 